bioRxiv preprint doi: https://doi.org/10.1101/435495; this version posted November 19, 2018. The copyright holder for this preprint (which was not certified by peer review) is the author/funder. All rights reserved. No reuse allowed without permission.

A meta-analysis of Entamoeba histolytica/dispar in Iraq

\title{
Khder Chalabi
}

The author is reviewing the methodology of the manuscript again and this will result in changing the final results of the study. 